\title{
Bowhead whale calf detections in the western Beaufort sea during the open water season, 2012-2019
}

\author{
J.T. Clarke, M.C. Ferguson, S.R. Okkonen, A.A. Brower, and A.L. Willoughby
}

\begin{abstract}
Successful reproduction is essential to a species existence. Here we summarize Bering-Chukchi-Beaufort (BCB) bowhead whale (Balaena mysticetus Linnaeus, 1758) calf distribution, ratio of calf to adult sightings, and encounter rate from data collected during line-transect aerial surveys conducted from July to October 2012-2019 in the western Beaufort Sea $\left(140^{\circ} \mathrm{W}-157^{\circ} \mathrm{W}\right)$. During 223,000 on effort $\mathrm{km}$, a total of 274 calves were seen: 100 in summer (July-August) and 174 in fall (September-October), compared with nearly 3,200 non-calves. Calves were widely distributed in the study area in August and September, with distribution in July largely east of $150^{\circ} \mathrm{W}$ and distribution in October west of $143^{\circ} \mathrm{W}$. Calf ratios and encounter rates appear to follow a 3-4 year cycle. Most calves (240/274; 88\%) were seen near an adult assumed to be the maternal female, but 9\% (26/274) of all calves were observed unaccompanied at the surface and $3 \%(8 / 274)$ were observed with large whales at the surface but not close by. Of the total calves detected, $60 \%(165 / 274)$ were observed after circling was initiated, highlighting the importance of closely investigating all bowhead whale sightings if identification of calves is critical to project goals. Bowhead whale calf data from the eastern Beaufort Sea and Amundsen Gulf in August 2019 are also summarized.
\end{abstract}

Key words: bowhead whale, Bering-Chukchi-Beaufort seas, calf ratio, seasonality, Pacific Arctic, aerial survey.

Résumé : Une reproduction réussie est essentielle à l'existence d'une espèce. Les auteurs résument ici la distribution des baleineaux de baleines boréales (Balaena mysticetus Linnaeus, 1758) de Béring-Chukchi-Beaufort (BCB), le rapport entre les observations de baleineaux et d'adultes et le taux de rencontre à partir des données recueillies lors des relevés aériens par transect linéaire effectués de juillet à octobre 2012-2019 dans l'ouest de la mer de Beaufort $\left(140^{\circ} \mathrm{O}-157^{\circ} \mathrm{O}\right)$. Au cours des $223000 \mathrm{~km}$ parcourus, un total de 274 baleineaux ont été vus : 100 en été (juillet-août) et 174 en automne (septembre-octobre), contre près de 3200 non-baleineaux. Les baleineaux étaient largement distribués dans la zone d'étude en août et septembre, la distribution en juillet étant largement à l'est du $150^{\circ} \mathrm{O}$ et la distribution en octobre à l'ouest du $143^{\circ} \mathrm{O}$. Les ratios de baleineaux et les taux de rencontre semblent suivre un cycle de $3-4$ ans. La plupart des baleineaux $(240 / 274 ; 88 \%)$ ont été vus près d'un adulte que l'on croit être la femelle maternelle, mais $9 \%(26 / 274)$ de tous

\footnotetext{
Received 23 April 2021. Accepted 22 December 2021.
}

J.T. Clarke. Cooperative Institute for Climate, Ocean and Ecosystem Studies, University of Washington, Seattle, WA 98105, USA.

M.C. Ferguson. NOAA, Alaska Fisheries Science Center, Marine Mammal Laboratory, Seattle, WA 98115, USA.

S.R. Okkonen. Institute of Marine Science, University of Alaska, Fairbanks, AK 99775, USA.

A.A. Brower and A.L. Willoughby. NOAA, Alaska Fisheries Science Center, Marine Mammal Laboratory, Seattle, WA 98115, USA; Cooperative Institute for Climate, Ocean and Ecosystem Studies, University of Washington, Seattle, WA 98105, USA.

Corresponding author: J.T. Clarke (e-mail: jclarke@wileylabs.net).

(C) 2022 The Author(s). This work is licensed under a Creative Commons Attribution 4.0 International License (CC BY 4.0), which permits unrestricted use, distribution, and reproduction in any medium, provided the original author(s) and source are credited. 
les baleineaux ont été observés non accompagnés à la surface et 3 \% (8/274) ont été observés avec de grandes baleines à la surface, mais pas à proximité. Sur le total des baleineaux détectés, 60 \% (165/274) ont été observés après le début de l'encerclement, ce qui souligne l'importance d'examiner de près toutes les observations de baleines boréales si l'identification des baleineaux est essentielle aux objectifs du projet. Les données sur les baleineaux des baleines boréales de l'est de la mer de Beaufort et du golfe d'Amundsen en août 2019 sont également résumées. [Traduit par la Rédaction]

Mots-clés : baleine boréale, mers de Béring-Chukchi-Beaufort, ratio de baleineaux, saisonnalité, Pacifique arctique, observation aérienne.

\section{Introduction}

A species cannot thrive if it does not successfully reproduce. Like most large cetaceans, bowhead whales (Balaena mysticetus Linnaeus, 1758) can reproduce every three or four years (Koski et al. 1993; George et al. 2011), but environmental conditions need to be advantageous for successful parturition. In the Pacific Arctic, environmental conditions in summer and fall have undergone extraordinary changes since 2000 (e.g., Wassman 2015; Moore 2018), exemplified most dramatically by the decrease in seasonal sea ice (Zhang et al. 2018). Additional changes are evident in warmer surface air and sea surface temperatures, decreased snow cover extent, thawing permafrost, decreased sea ice thickness (RichterMenge et al. 2019), and increased net primary production (Frey et al. 2017; Hill et al. 2018). The impacts of these environmental changes on marine life endemic to the Pacific Arctic, including bowhead whales, have been the subject of several recent studies (Ashjian et al. 2010; George et al. 2015; Moore 2016; Clarke et al. 2016, 2018; Druckenmiller et al. 2018; Okkonen et al. 2018).

Bowhead whales of the Bering-Chukchi-Beaufort (BCB) seas stock winter in the northern Bering Sea and undertake a directed migration each spring, using open leads nearshore in the eastern Chukchi Sea and offshore in the western Beaufort Sea, to the eastern Beaufort Sea and Amundsen Gulf in Arctic Canada (Moore and Reeves 1993; Citta et al. 2021). During summer, although most BCB bowhead whales take advantage of productive feeding areas in Canada, some whales may remain in the western Chukchi Sea north of the Chukotka peninsula (Moore et al. 1995; Melnikov and Zeh 2007), in the northeastern Chukchi Sea north and west of Alaska (Moore 1992; Moore et al. 2012), and in the western Beaufort Sea (Moore et al. 2010; Clarke et al. 2018). Satellite-tagged whales have demonstrated dispersion throughout the summer range, from the eastern Beaufort Sea to areas north of Wrangel Island in the western Chukchi Sea (Citta et al. 2021). In fall, bowhead whales commence a return migration to the northern Bering Sea that is generally less directed than the spring migration, and satellite tag data indicate that they are generally absent from the Beaufort Sea by November (Citta et al. 2021). Bowhead whales feed on euphausiids and copepods throughout their range (Lowry and Frost 1984; Sheffield and George 2021), the availability of which are likely a main driver of distribution and abundance. Dense aggregations of bowhead whale prey occur near frontal features where upwelling occurs (Ashjian et al. 2010; Okkonen et al. 2011, 2016; Citta et al. 2015). Obtaining direct evidence of upwelling and prey aggregations is difficult, but investigations of winds and other oceanographic phenomena via remote sensing have been used as proxies for direct observations. Additionally, remote teleconnections are known to drive some of the spatiotemporal variability in bowhead whale density wherein physical or biological conditions present in one area and period may affect bowhead whale density in a different location at a later date (Ashjian et al. 2021; Ferguson et al. 2021). 
In the mid-19th century, Yankee whalers referred to the area in the southwestern Chukchi Sea, near Cape Serdtse-Kamen, Chukotka, as the "cow yard" due to the large, slow-swimming bowhead whales that were harvested there (Bockstoce 1986). Here, we present data on a modern day "cow yard" in the western Beaufort Sea (WBS) using data collected during aerial surveys conducted in the WBS from 2012 to 2019. Aerial surveys can cover a broad spatio-temporal range and allow collection of bowhead whale calf-ofthe-year (hereafter "calf" unless otherwise noted) distribution and encounter rate data that would be difficult to acquire by any other means currently available. These data allow us to make inferences about spatio-temporal patterns in bowhead whale calf (referred to as agvaaq by the Iňupiat of northern Alaska) distribution and encounter rate in the WBS. We compare 2012-2019 results with historical aerial survey data from fall 1982-2011. Finally, bowhead whale calf distribution, calf ratio, and encounter rate from aerial surveys conducted in the eastern Beaufort Sea and Amundsen Gulf (EBS-AG) in August 2019 are also included to provide a context for interpreting observations from the WBS.

\section{Materials and methods}

\section{Survey methodology}

The Aerial Surveys of Arctic Marine Mammals (ASAMM) project conducted aerial surveys during fall (September-October) in the WBS $\left(140^{\circ} \mathrm{W}-157^{\circ} \mathrm{W}\right)$ every year from 1982 to 2019 , providing data on $\mathrm{BCB}$ bowhead whale distribution, behavior, and encounter rate (number of whales observed per unit survey effort). Starting in 2012, aerial survey effort in the WBS expanded to include summer months (July-August). The addition of annually recurring summer surveys and changes to survey protocols (e.g., survey platforms, computing capability, stricter line-transect methodology; see Clarke et al. 2016 for a complete discussion of refinements) necessitated that subsets of the complete ASAMM dataset be used to investigate bowhead whale calves (Table 1).

The WBS study area extended from shore up to $300 \mathrm{~km}$ offshore, an area encompassing $131,000 \mathrm{~km}^{2}$ (Fig. 1). Line-transect aerial surveys were flown in the WBS study area from early July to late October 2012-2019 in Turbo Commander aircraft. The EBS-AG study area extended from $118^{\circ} \mathrm{W}$ to $140^{\circ} \mathrm{W}$, up to $190 \mathrm{~km}$ offshore, an area totaling $177,000 \mathrm{~km}^{2}$ (Fig. 1). Surveys were conducted in the EBS-AG study area from 7 to 27 August 2019 in Turbo Commander and De Havilland Twin Otter aircraft. All survey aircraft used in 2012-2019 were outfitted with left- and right-side bubble windows, and survey protocols were identical in both study areas. Surveys were flown at 305 to $460 \mathrm{~m}$ altitude, maintaining a survey speed of approximately $204 \mathrm{~km} / \mathrm{h}$. Surveys were not conducted when surface wind force was above Beaufort 5 or cloud ceilings were consistently less than $335 \mathrm{~m}$. Transects were located every half degree of longitude and oriented perpendicular to shore to sample across isobaths, prevailing currents, and expected gradients in marine mammal density. Two primary observers continuously scanned for marine mammals, one on each side of the aircraft, whereas a third observer/data recorder entered data into a laptop computer for each sighting, whenever survey conditions changed, or every 5 minutes.

Sightings by primary observers on transect were considered "on effort". Most on effort large whale (mysticete) sightings were briefly $(<10 \mathrm{~min})$ circled to identify sightings to species, estimate group size, and search for calves. Whales detected during circling that were part of the original sighting group (i.e., within a few body lengths) were also considered on effort, whereas whales that were not associated with the original sighting were considered off effort. Beginning in 2018, Cetacean Aggregation Protocols (CAPs) were initiated in areas where cetacean aggregations were so dense that observers could no longer effectively mark and investigate each sighting. During CAPs, sighting data for the aggregation were collected as completely as possible from the transect (e.g., CAPs passing), followed 
Table 1. Aerial Survey of Arctic Marine Mammals (ASAMM) data subsets used for analysis.

\begin{tabular}{|c|c|c|c|c|c|}
\hline ASAMM Data Subset & Study Area & Years & Months & Analysis & Rationale \\
\hline $\begin{array}{l}\text { Sightings on transect, CAPs passing, } \\
\text { and brief circling from transect; } \\
\text { primary observers }\end{array}$ & WBS & 2012-2019 & July-October & $\begin{array}{l}\text { Calf ratio, calf } \\
\text { encounter rate }\end{array}$ & $\begin{array}{l}\text { Incorporates strongest line-transect data } \\
\text { within the time and area specified; transect } \\
\text { and CAPs passing are equivalent methods. }\end{array}$ \\
\hline $\begin{array}{l}\text { Sightings on transect, CAPs passing, } \\
\text { and brief circling from transect; } \\
\text { primary observers }\end{array}$ & EBS-AG & 2019 & August & $\begin{array}{l}\text { Calf ratio, calf } \\
\text { encounter rate }\end{array}$ & $\begin{array}{l}\text { Incorporates strongest line-transect data } \\
\text { within the time and area specified; transect } \\
\text { and CAPs passing are equivalent methods. }\end{array}$ \\
\hline $\begin{array}{l}\text { Effort }(\mathrm{km}) \text { on transect and CAPs } \\
\text { passing }\end{array}$ & WBS & 2012-2019 & July-October & Calf encounter rate & $\begin{array}{l}\text { Incorporates strongest line-transect data } \\
\text { within the time and area specified; transect } \\
\text { and CAPs passing are equivalent methods. }\end{array}$ \\
\hline $\begin{array}{l}\text { Sightings on transect and CAPs } \\
\text { passing (no circling); all observers }\end{array}$ & WBS & 1982-2019 & September-October & Calf ratio & $\begin{array}{l}\text { Limited to months when data were available } \\
\text { for several years in succession; all observers } \\
\text { because primary observers were not } \\
\text { recorded prior to } 1990\end{array}$ \\
\hline
\end{tabular}

Note: CAPs, Cetacean Aggregation Protocols; WBS, western Beaufort Sea; EBS-AG, eastern Beaufort Sea and Amundsen Gulf. 
Fig. 1 Western Beaufort Sea study area, eastern Beaufort Sea and Amundsen Gulf study area, and sample transects for the Aerial Surveys of Arctic Marine Mammals (ASAMM) project. Inset map shows the location of the study area relative to the Pacific Arctic. Map drawn using ESRI ArcGIS Desktop Version 10.6.1, and assembled using shapefiles from ArcGIS World Map and International Bathymetric Chart of the Arctic Ocean Version 3.0 (Jakobsson et al. 2012).

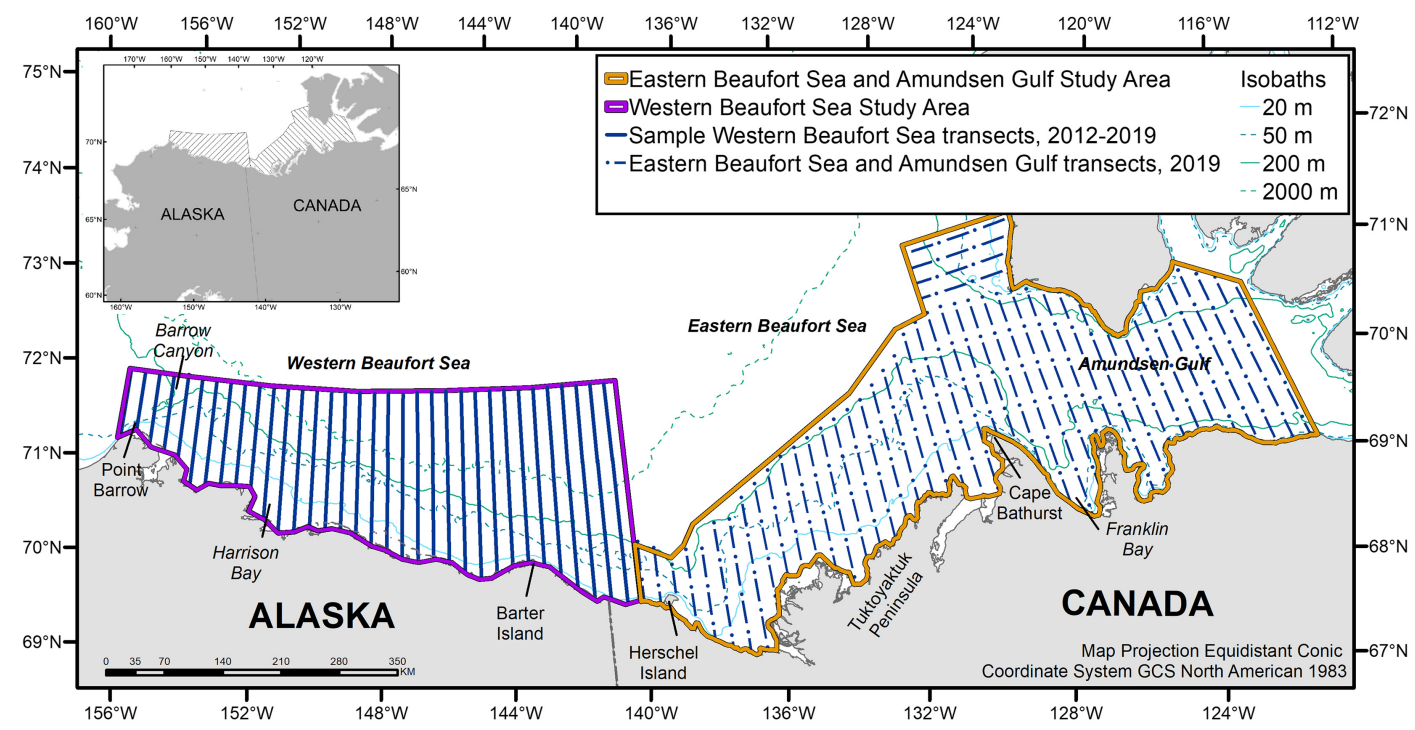

by CAPs circling during which additional detailed information on the aggregation were recorded. Only data collected on transect and during CAPs passing were considered on effort and included in analyses. Whales were classified as calf-of-the-year when an experienced observer noted a combination of the following characteristics: noticeably smaller size, lighter gray color, smaller head compared with overall body size, and close association with an adult. When survey conditions allowed, photographs were taken of many, but not all, calves, and images reviewed post-survey by experts to confirm age class. Additional survey protocol details are provided elsewhere (e.g., Clarke et al. 2020). Aerial surveys in the WBS study area followed guidelines prescribed in research permits from the U.S. National Marine Fisheries Service (Permit Nos. 14245 and 20465) and the U.S. Fish and Wildlife Service (Permit No. MA212570-1). Aerial surveys in the EBS-AG study area were approved by the Inuvialuit Game Council and the Joint Game Management Committee.

Line-transect aerial surveys in the WBS in 1982-2011 were conducted using similar protocols to those conducted in 2012-2019 but differed in a few important details. Survey platforms prior to 1992 did not always include bubble windows, limiting downward visibility, and several surveys were conducted at higher speeds. Primary observers were not consistently identified in the database prior to 1990 . Circling was not consistently recorded prior to 2009. Lastly, widespread survey coverage in the WBS was limited to September and October prior to 2012. Analyses using the 1982-2011 database were modified to accommodate these differences.

\section{Calf ratio and encounter rate}

Calf ratio is the proportion of the population surveyed that are calves, a function of calf production. Calf ratio was calculated as the proportion of bowhead whale calves observed on effort relative to total bowhead whales observed on effort. Calf ratio for 2012-2019 was calculated seasonally (summer: July-August; fall: September-October) and annually. For fall 1982-2019, calf ratio was calculated annually using a modified data subset comprising all 
sightings detected on effort regardless of observer type (i.e., primary and secondary) from September and October only, and which excluded all sightings made during circling (Table 1).

Calf encounter rate normalizes the number of calf observations by the amount of survey effort, providing an index of the relative density of calves in the study area. Encounter rates (calves on effort per kilometre on effort) were calculated using calves on effort in July-October 2012-2019. Encounter rates can be considered a measure of relative density because they were not corrected for availability or perception bias (Buckland 2001). Encounter rates were calculated seasonally and annually for the combined WBS study area, and monthly in a hexagonal grid with $25 \mathrm{~km}$ resolution. Encounter rates for the EBS-AG study area were also calculated in the hexagonal grid for August 2019. Distance on effort $(\mathrm{km})$ per hexagonal cell was calculated using $R$ version 3.6.2 (R Core Team 2019) using packages sp (Pebesma and Bivand 2005; Bivand et al. 2013), maptools (Bivand and Lewin-Koh 2019), raster (Hijmans 2020), rgeos (Bivand and Rundel 2019), rgdal (Bivand et al. 2019), and mgcv (Wood 2017).

\section{Environmental variables}

Median depth and distance from shore were used to investigate potential differences in central tendency distribution between calf and non-calf groups (Clarke et al. 2020). Non-calf groups excluded sightings of maternal females (cows with calves) and calves sighted alone at the surface. The non-parametric Mann-Whitney U-test was used to examine differences between median depth and distance from shore at on effort calf sightings and median depth and distance from shore at on effort non-calf sightings per month for all years pooled, 2012-2019, to provide a metric for comparing monthly calf distribution with the distribution of non-calves. Distance from shore is closely correlated with bathymetry in the western Beaufort Sea, with the $50 \mathrm{~m}$ and $200 \mathrm{~m}$ isobaths equidistant from shore except near Barrow Canyon (see Supplementary Fig. S1 $1^{1}$ ).

\section{Results}

The WBS study area was surveyed extensively from July to October 2012-2019, with $>223,000 \mathrm{~km}$ flown on effort (Supplementary Fig. S1 ${ }^{1}$ ). A total of 274 bowhead whale calves were seen on effort in July-October 2012-2019, (compared with 3,186 non-calf bowhead whales), including 100 calves in summer (July-August) and 174 calves in fall (September-October) (Table 2). Bowhead whale calves were seen in all months (Supplementary Fig. S1 ${ }^{1}$ ) and in all years. Total calves per year varied from 11 (2014) to 76 (2017) (Table 2). Calf distribution in July was primarily east of $150^{\circ} \mathrm{W}$ (Supplementary Fig. $S 1 A^{1}$ ) and in the deepest water and farthest from shore of all open water months (Table 3). Calves were widely distributed in the study area in August, although most calves were still observed east of $150^{\circ} \mathrm{W}$ (Supplementary Fig. S1B ${ }^{1}$ ), and median depths and distances from shore were less than those observed in July (Table 3). Distribution was most widespread in September, with calves observed throughout the study area (Supplementary Fig. S1C ${ }^{1}$ ) at the shallowest median depths and distances from shore of all open water months (Table 3). Calf distribution in October was primarily west of $143^{\circ} \mathrm{W}$ (Supplementary Fig. $\mathrm{S}^{1} \mathrm{D}^{1}$ ) with median depths and distances to shore intermediate to those seen in August and September (Table 3). Bowhead whale cow-calf pairs (and unaccompanied calves) were found significantly $(p<0.001)$ farther from shore than all other bowhead whales in August

\footnotetext{
${ }^{1}$ Supplementary data are available with the article at https://doi.org/10.1139/as-2021-0020.
} 
Table 2. Summer (July-August pooled) and fall (September-October pooled) subtotals of calf-of-the-year and non-calf bowhead whales observed on effort annually in the western Beaufort Sea, 2012-2019.

\begin{tabular}{lccccc}
\hline & \multicolumn{2}{l}{ Summer } & & \multicolumn{2}{l}{ Fall } \\
\cline { 2 - 3 } \cline { 5 - 6 } Year & Non-calf & Calf-of-the-year & & Non-calf & Calf-of-the-year \\
\hline 2012 & 69 & 6 & & 128 & 6 \\
2013 & 215 & 20 & 99 & 14 \\
2014 & 110 & 5 & 233 & 6 \\
2015 & 90 & 3 & 297 & 15 \\
2016 & 560 & 24 & 261 & 39 \\
2017 & 186 & 31 & 378 & 45 \\
2018 & 44 & 3 & 290 & 14 \\
2019 & 75 & 8 & 151 & 35 \\
Total & 1,349 & 100 & 1,837 & 174 \\
\hline
\end{tabular}

Table 3. Monthly central tendency statistics for bowhead whale calf-of-the-year sighting locations, 2012-2019 pooled.

\begin{tabular}{llllllll}
\hline & \multicolumn{2}{l}{ Depth $(\mathrm{m})$} & & \multicolumn{3}{l}{ Distance from Shore $(\mathrm{km})$} \\
\cline { 2 - 4 } Month & Mean & Median & Range & & Mean & Median & Range \\
\hline July & 330 & 52.5 & $26-2,357$ & & 53.3 & 54.2 & $10.6-115.0$ \\
August & 179 & 45.5 & $17-2,266$ & & 44.4 & 40.1 & $7.9-133.8$ \\
September & 82 & 38 & $6-816$ & & 35.1 & 29.2 & $1.1-88.6$ \\
October & 76 & 45 & $10-312$ & & 38.3 & 33.6 & $4.5-91.5$ \\
\hline
\end{tabular}

and September; cow-calf pairs and calves were also observed farther from shore in October, but the difference was not significant.

Calves were usually seen in close association with an adult, presumed to be the maternal female. Thirty-four unaccompanied calves were sighted, of which eight were in the general vicinity of adult whales engaged in feeding and 26 were observed without any adult whales visible. On two occasions, one adult bowhead whale was observed accompanied by two calves. Calves were rarely (4\%) sighted first (i.e., before an adult whale) from the trackline; an adult whale was usually the initial sighting, with calves sighted secondarily from the transect or during subsequent circling. Sixty percent of calves detected in 2012-2019 were first observed after brief circling was initiated and would not otherwise have been detected.

\section{Calf ratios and encounter rates}

Annual bowhead whale calf ratios from 2012 to 2019 varied from year to year. Annual calf ratios were highest in 2019 (0.1599), 2017 (0.1188), and 2013 (0.0977) and lowest in 2014, 2015, and 2018 (years with calf ratios $<0.0500$ ) (Fig. 2A). The highest bowhead whale calf ratio per season was in summer 2017 (0.1429) and fall 2019 (0.1882). Intra-annually, summer calf ratio was higher than fall calf ratio in four of the eight years (2012, 2014, 2017, and 2018).

Examining ASAMM calf data dating back to 1982, fall calf ratios in the WBS ranged from 0 (seven years) to 0.094 (1991). Fall calf ratios were highest in 1983, 1986, 1991, 1997, 2001, 2004, 2005, 2008, 2009, 2013, 2017, and 2019 (Fig. 3). The high calf ratios in 1983, 1986, 1991, and 2001 all occurred during years when multiple calves were seen relative to very few total bowhead whale sightings (Fig. 3). Most (86\%) of the years when fall calf ratios were 0 occurred between 1982 and 2008. Between 1982 and 2008, fall calf ratios were $>0.0400$ in eight years (30\%), whereas fall calf ratios between 2009 and 2019 were $>0.0400$ in four years 
Fig. 2 Bowhead whale annual calf ratios (number of calves on effort relative to total whales on effort) (A) and encounter rates (calves per on effort km) (B) in summer (July-August pooled), fall (September-October pooled), and annually (July-October pooled) in the western Beaufort Sea, 2012-2019.
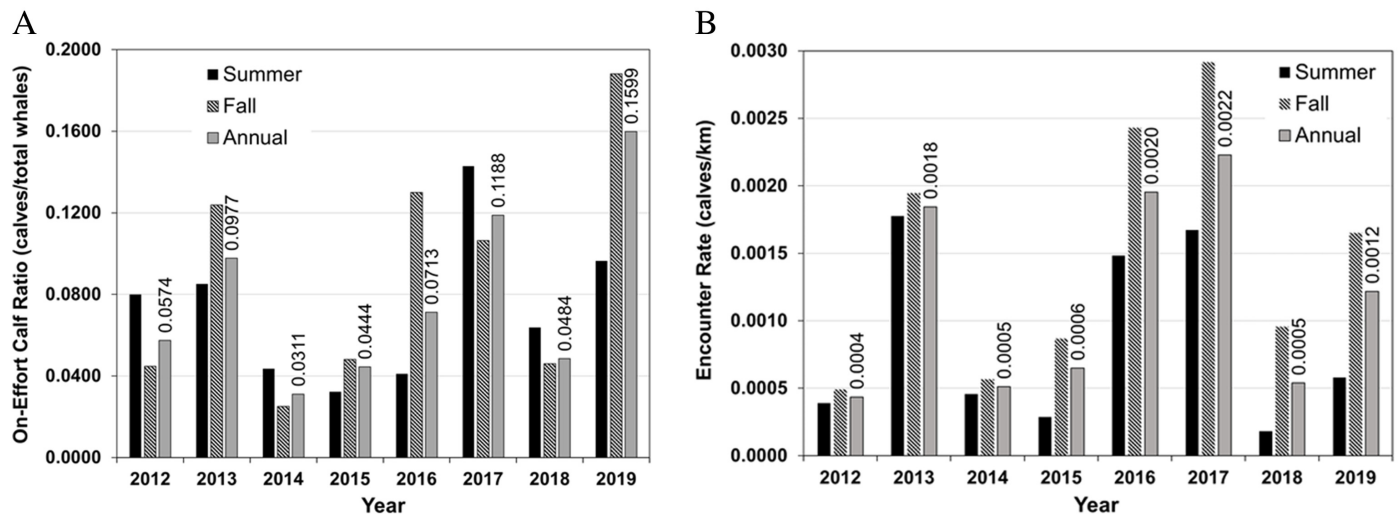

Fig. 3 Bowhead whale annual calf ratios (number of calves on effort relative to total whales on effort) in fall (September-October pooled) in the western Beaufort Sea, 1982-2019. Calf ratios incorporate sightings from primary and secondary observers but exclude any sightings made during circling. Data labels indicate number of calves per total number of whales.

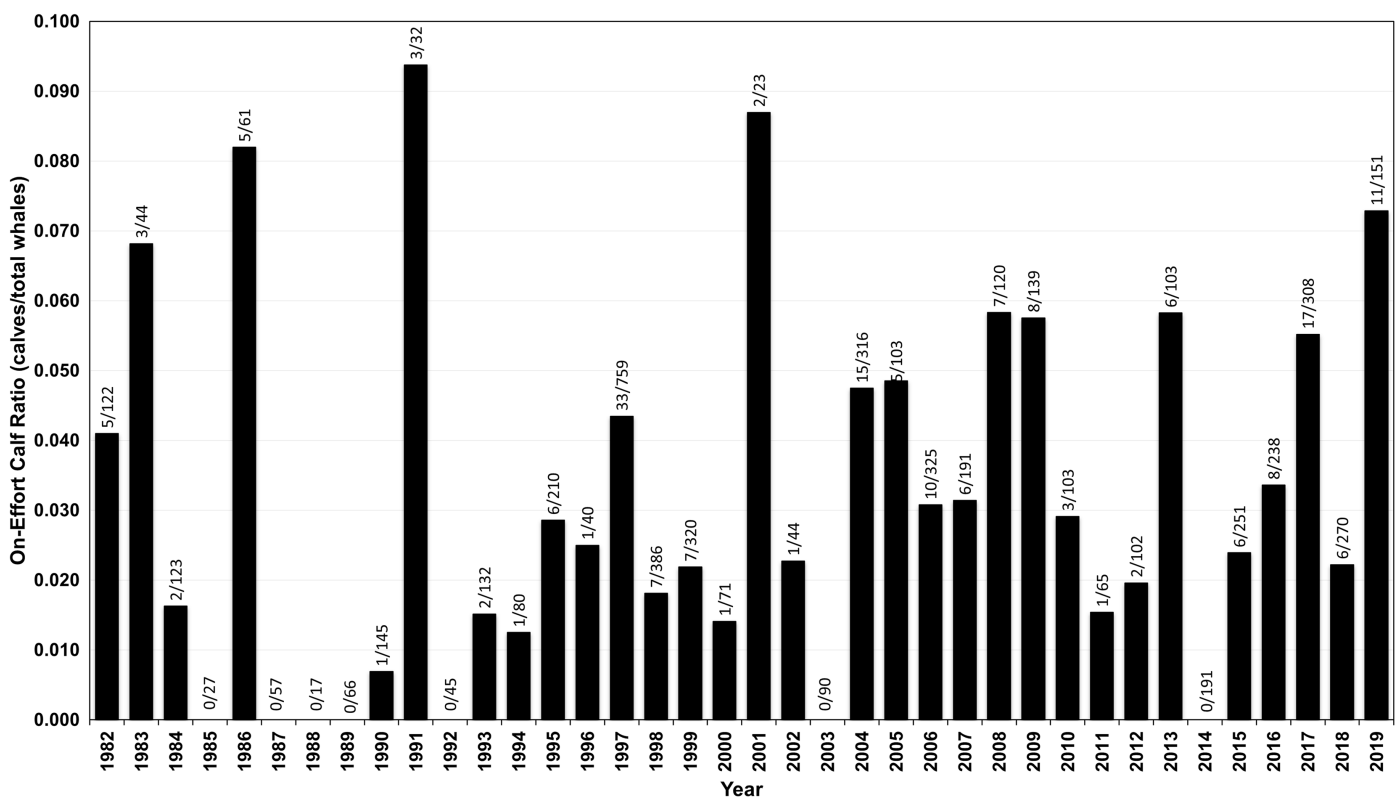

(36\%) (Fig. 3). Starting in 1997, calf ratios from ASAMM data peaked at 3-4 year intervals except between 2017 and 2019, when the interval was two years.

Calf encounter rates for summer and fall (pooled) were highest $(\geq 0.0020$ calves per $\mathrm{km})$ in 2016 and 2017, and lowest $(\leq 0.0006)$ in 2012, 2014, 2015, and 2018 (Fig. 2B). Per year, summer calf encounter rates were highest in 2013; fall calf encounter rates were highest in 2017. Monthly encounter rates for all years pooled were highest in cells east of $143^{\circ} \mathrm{W}$ in 
Fig. 4 Bowhead whale calf encounter rates (calves per on effort km), western Beaufort Sea, 2012-2019 pooled, July (A), August (B), September (C), and October (D). Empty cells indicate effort but no sightings. The black box in Fig. 4B denotes a cell also shown in Fig. 5. Map drawn using ESRI ArcGIS Desktop Version 10.6.1 and assembled using shapefiles from ArcGIS World Map and International Bathymetric Chart of the Arctic Ocean Version 3.0 (Jakobsson et al. 2012).
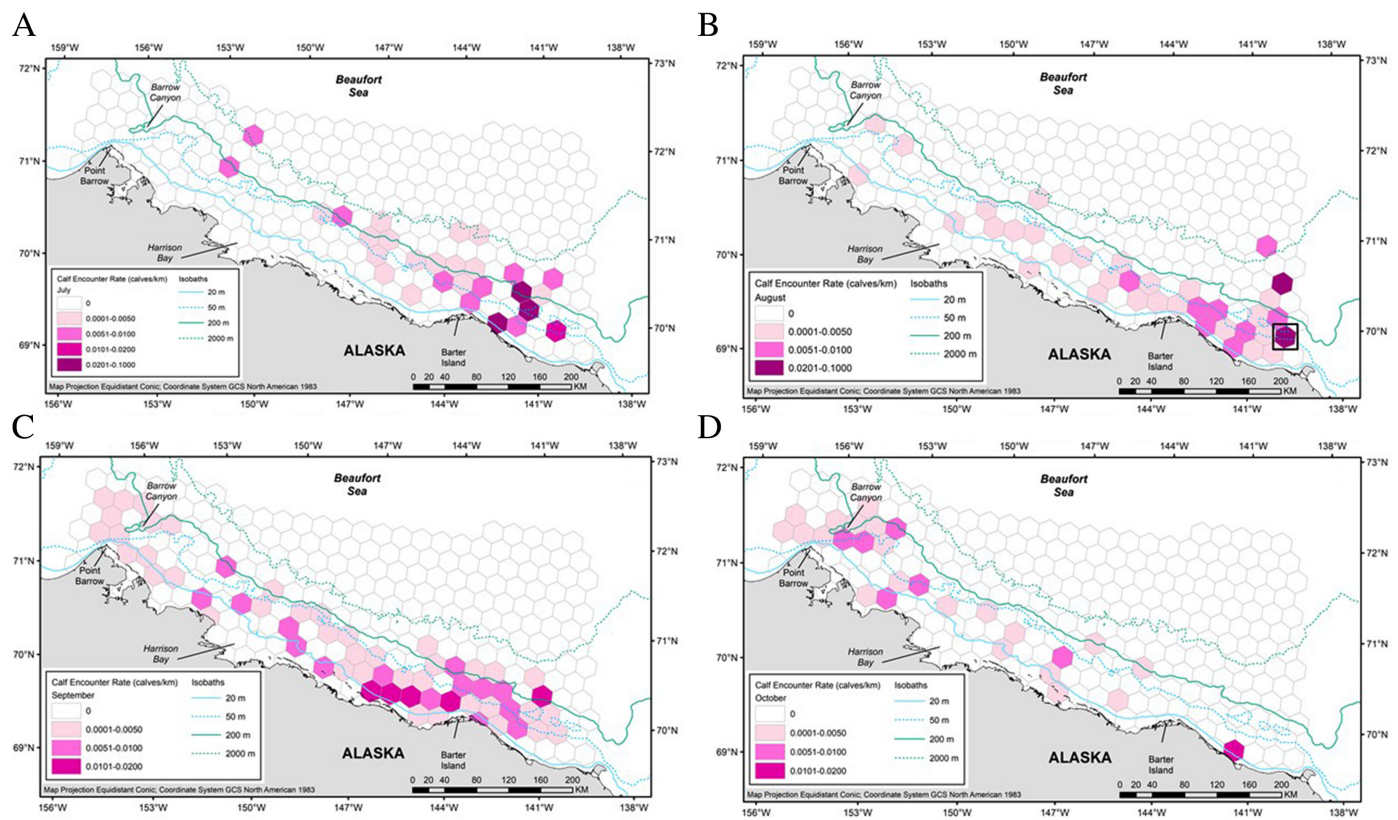

July and August (Fig. 4A and 4B), including areas where depth exceeded $200 \mathrm{~m}$. Cells with relatively high encounter rates were spatially more widespread in September (Fig. 4C) and less predominant in October (Fig. 4D).

\section{Eastern Beaufort Sea}

The EBS-AG study area was surveyed in August 2019, with 2,400 km on effort. Fifty-four calves were observed for a calf ratio of 0.1738; no calves were observed in the WBS during the same period. Calves were clustered in three distinct areas: north of Herschel Island (sighting depth: mean $168 \mathrm{~m}$, median $148 \mathrm{~m}$ ), northwest of the Tuktoyaktuk Peninsula (sighting depth: mean $53 \mathrm{~m}$, median $57 \mathrm{~m}$ ), and north of Cape Bathurst (sighting depth: mean 113 m, median 100.5 m) (Fig. 5). Calves were not seen in Franklin Bay, immediately east of Cape Bathurst, despite the high density of bowhead whale sightings there (Clarke et al. 2020), nor were they seen in Amundsen Gulf.

\section{Discussion}

Visual observations from a standardized, long-term, line-transect aerial survey project have provided new and updated insights into spatiotemporal variability of BCB bowhead whale calf habitat use (calf encounter rates) and productivity (calf ratios) in the western Beaufort Sea. This information may provide clues as to how changes in the Pacific Arctic over the past few decades may have affected the BCB bowhead whale population, and what the future may hold.

Bowhead whale calves are commonly observed in the WBS by mid-July and remain in the area, albeit at lower rates of detection, through late October, which is a longer period than 
Fig. 5 Bowhead whale calf encounter rates (calves per on effort km), eastern Beaufort Sea and Amundsen Gulf, August 2019. Empty cells indicate effort but no sightings. The black box denotes a cell also shown in Fig. 4B. Map drawn using ESRI ArcGIS Desktop Version 10.6.1 and assembled using shapefiles from ArcGIS World Map and International Bathymetric Chart of the Arctic Ocean Version 3.0 (Jakobsson et al. 2012).

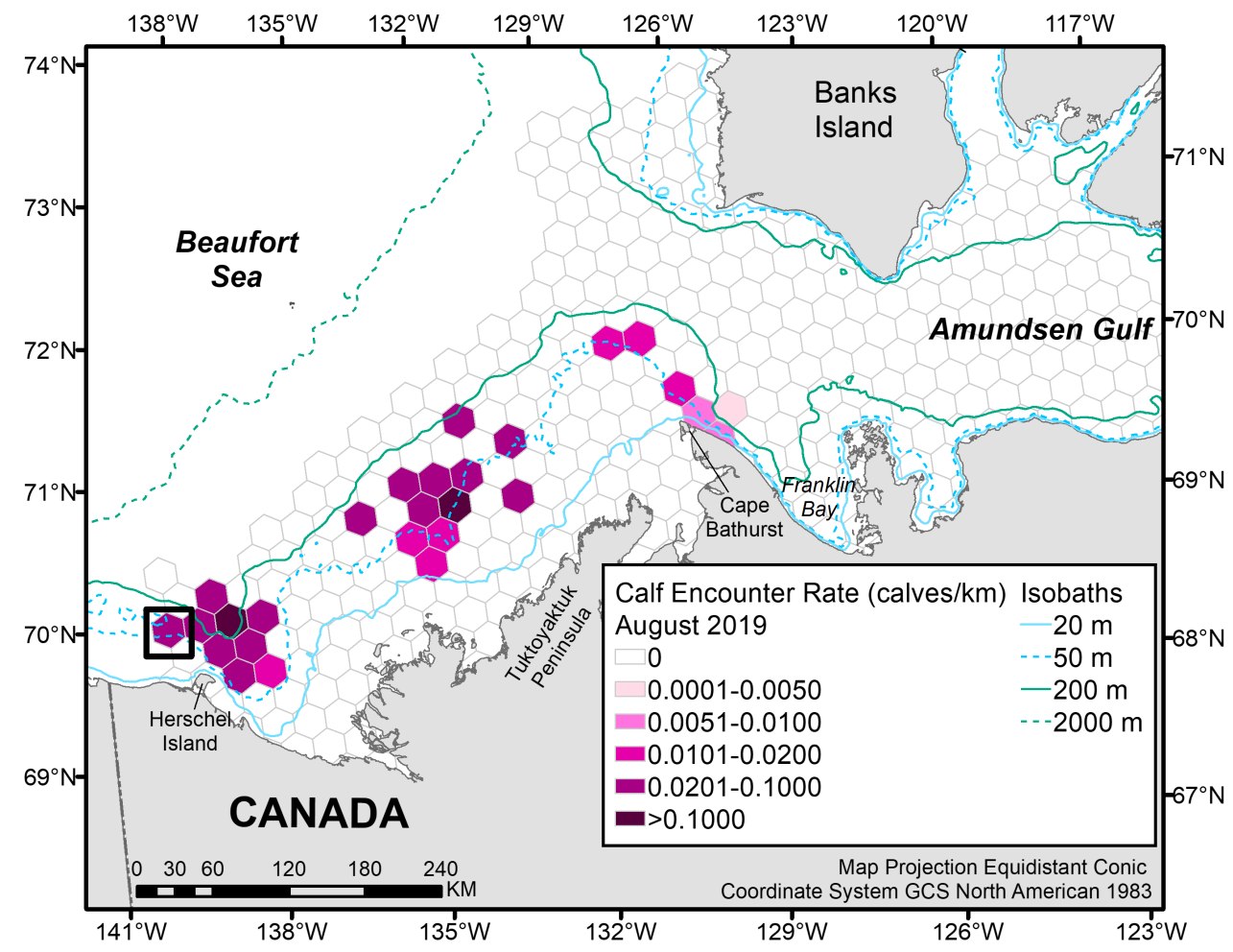

that suggested by Koski and Miller (2009). Using data collected from mid-August to early October in 1982, 1984-1986, and 1998-2000 in the western Alaska Beaufort Sea $\left(139^{\circ} \mathrm{W}-146^{\circ} \mathrm{W}\right)$, Koski and Miller (2009) suggested that maternal females arrived in that area in early September and were common until at least early October.

Most bowhead whale calves are born between the beginning of April and end of May (Tarpley et al. 2021), but calving may occur as late as August (Koski et al. 1993). Calves observed in the WBS in July and August may be only a few months old, whereas calves observed in September and October may be close to six months of age and close to weaning (George et al. 2021). Young calves likely spend more time at the surface than older calves due to the inability of younger calves to dive for as long (Würsig and Clark 1993). Higher calf ratios in summer 2012, 2014, 2017, and 2018 compared with fall may be due to later calving in those years, resulting in increased calf detections in the WBS of younger calves who spent more time at the surface. Younger calves visible at or near the surface for longer periods may also explain why the highest encounter rates per month per cell occurred in July and August (Fig. 4A and B). Cow-calf pairs in the WBS may not undergo directed one-way movements (e.g., west or northwest), and may move west, east, north, or all of those directions, as satellite tag data have shown of adult and juvenile bowhead whales (Citta et al. 2021). Cow-calf pairs may also exit the WBS in September and October, although the direction of movement could potentially be either east to the EBS or west to the Chukchi Sea. 
A key finding of this study was the importance of incorporating brief circling into survey methodology to improve detection of calves. Bowhead whale calves were rarely detected initially from the trackline, likely because of their smaller size and sighting cues like body or blow that were less obvious. Calves may be only one-third the length of adults. Newborn calves average about $4.6 \mathrm{~m}$ length (range 3.6 to $5.3 \mathrm{~m}$ ), whereas fall harvested calves averaged $6.7 \mathrm{~m}$ (George et al. 2021). Sexually mature whales aged mid-20s are about 13.0-13.5 m, whereas measurements of older bowhead whales (taken via aerial photogrammetry and directly from harvested whales) have exceeded $17 \mathrm{~m}$ length (George et al. 2021). The relatively smaller size of calves compared with non-calves negatively biases calf detection, and detection further decreases as distance from the trackline increases. The calf's blow, or forced expulsion of hot air from the lungs via the blowholes that turns water near the blowhole into mist, is smaller and less defined and, therefore, also harder to detect. Calf detection bias may be one of the causes for the difference in calf detections between surveys conducted by ASAMM in the EBS-AG study area in August 2019 compared with surveys conducted in the EBS in August 2007-2009. The 54 calves observed in August 2019 were considerably more than the 10 calves sighted by Harwood et al. (2010) within their study area $\left(128^{\circ} \mathrm{W}\right.$ to $\left.141^{\circ} \mathrm{W}\right)$ during surveys conducted in August 2007-2009. The EBS aerial surveys in 2007-2009 intentionally did not include departures from transect to circle sightings (Harwood et al. 2010) and had fewer calf detections compared with the 2019 ASAMM survey that included brief circling. Quantitative comparisons of the relative abundance of calves between 2007 and 2009 and in 2019 are not possible, but the general patterns of distribution of bowhead whales, including calves, were similar in the earlier series and in 2019. Calf distribution in August 2019 mirrored the distribution reported by Harwood et al. (2010) for 2007-2009; the latter study did not extend as far east as Franklin Bay or Amundsen Gulf. Franklin Bay and Amundsen Gulf were used mainly by adults and large subadults in 1984-1986 (Koski et al. 1988), and large adults were noted in Franklin Bay in August 2019 (Clarke et al. 2020). Differences in calf ratio between years also likely reflect the annual variability in bowhead whale occurrence and distribution throughout their summer range as documented by aerial surveys (Clarke et al. 2020; Ferguson et al. 2021; Koski et al. 1988), satellite telemetry (Citta et al. 2021; Harwood et al. 2017), and passive acoustics (Blackwell et al. 2007).

Dive and surface times were collected during a dedicated focal group follow conducted during an ASAMM survey in July 2019 on a cow-calf pair observed $\sim 60 \mathrm{~km}$ north of Barter Island, Alaska, using methods described by Clarke et al. (2019). The calf was approximately one-third the length of the cow and light gray in color; the cow had distinct scarring that ensured reidentification. During this 103 minute behavioral sequence, the calf was visible $94 \%$ of the total observation time, whereas the cow was visible only $19 \%$ of the time (Marine Mammal Laboratory, Aerial Surveys of Arctic Marine Mammals, unpublished data, 2019). When both cow and calf were visible, which occurred four times after the initial sighting, they were within a few body lengths of each other on only two occasions for $12 \%$ of the total time, which differs from behavioral observations from other studies of bowhead whale cow-calf pairs in which cows and calves remained consistently in close proximity to each other (e.g., Würsig et al.1985). During the other two instances when both the cow and calf were visible, they were separated by $>1 \mathrm{~km}$ and did not meet at the surface before the cow dived. When the calf alone was visible during the 2019 behavioral sequence, we assumed that the cow was likely feeding subsurface; her dive times ranged from 8 to 28 min. The amount of time the calf was visible alone at the surface sheds light on the frequency of ASAMM observations of solo calves (with no adult nearby) and might explain adult whales observed with multiple calves. 
The spatio-temporal distribution of calves in the WBS was not surprising based on other assessments of bowhead whales in the region (e.g., Clarke et al. 2018). Bowhead whales tend to be farther from shore and in deeper water in July compared with August-October (Clarke et al. 2018), so it follows that calves likely still dependent on their mothers for nutrition were also found most frequently in water depths exceeding $50 \mathrm{~m}$ in July. The only region where temporal segregation between calves and non-calves appeared to occur was in summer in the western Alaskan Beaufort Sea. This area is the greatest distance from the eastern Beaufort Sea where most BCB bowhead whales are presumed to feed in summer, and the absence of calves west of $150^{\circ} \mathrm{W}$ in summer reflects this. Spatial segregation between sightings with calves and sightings without calves, based on distance from shore, was evident in all months of this study and has also been documented for BCB bowhead whales during the spring migration. Maternal females with newborn calves are the last to migrate past Point Barrow en route to the Beaufort Sea in spring (Würsig and Clark 1993), perhaps delaying migration from the Bering Sea to allow the calves to gain strength and stamina. Sexual segregation by bowhead whales has also been observed in the Baffin Bay stock, with mature whales without calves occupying Disko Bay, Greenland, and nursing females, calves, and subadults of this stock more often using areas west of Baffin Island, Nunavut, Canada (Heide-Jørgensen et al. 2010). Segregation by cow-calf pairs has been noted in other cetaceans that also do not have monogamous mating systems, particularly mysticetes. Eastern North Pacific gray whale (Eschrichtius robustus (Lilljeborg, 1861)) maternal females with newborn calves are the last to migrate from the protected lagoons of Baja California, Mexico, northward along the west coast of North America (Rice et al. 1984). Central North Pacific humpback whale (Megaptera novaeangliae (Borowski, 1781)) pods containing a calf occur in significantly shallower water than pods without calves near Maui, Hawaii, USA, as do maternal females with calves lacking a male escort (Craig et al. 2014). Humpback whale juveniles and females without calves also arrive on and depart from wintering grounds in the Hawaiian Islands earlier than do males and maternal females (Craig et al. 2003).

Calf ratios and calf encounter rates from ASAMM data collected since 2012 were highest in 2013, 2016, 2017, and 2019 (Fig. 2). Assuming the calf ratios observed in our sample reflect those of the $\mathrm{BCB}$ population as a whole, the peaks in observed calf ratios are similar to the 3-4 year BCB calving interval suggested by George et al. (2011) and Koski et al. (1993) based on data obtained from subsistence harvested females and during ice-based censuses. Calf ratio and encounter rate were especially high in 2017, indicating that 2016 may have been a particularly favorable year for conception and pregnancy, or that 2017 was particularly favorable for calf survival. Calf ratio was not as high in 2016; however, calf ratio in summer 2016 was likely biased downward because of the inability to accurately record calves during one survey in August when nearly 500 feeding bowhead whales were seen in a relatively small area $\left(\sim 1,900 \mathrm{~km}^{2}\right)$ over a short period of time $(\sim 2 \mathrm{~h})$ (Clarke et al. 2018).

Calf ratios in the WBS in fall 1982-2019 also display peaks every 3-4 years (Fig. 3) but exhibited dramatic differences from one year to the next even when the data were "normalized" across all years by removing any bowhead whales observed during circling. Environmental conditions including, but not limited to, sea ice extent, ocean temperature, presence of predators, and availability of prey for maternal females, undoubtedly affect calf survival and, therefore, calf ratio. Differences in survey platforms and methods likely also affected calf ratio. Four of the six years during which no calves were seen occurred from 1982 to 1991. Survey platforms used from 1982 to 1991 did not always have bubble windows, which limited downward visibility of the trackline, likely reducing the probability of detecting a 4-5 m calf. Most of the surveys during the early years (1982-1991) were also conducted at a higher survey speed $(\sim 270 \mathrm{~km} / \mathrm{hr})$. Additionally, the preferred survey altitude 
from 1982 to 2014 was $460 \mathrm{~m}$ in the WBS study area, with preferred survey altitudes $<400 \mathrm{~m}$ in later years, which were also more conducive to detecting smaller cetaceans like bowhead whale calves. Complementary information about bowhead whale fall migration habitat (e.g., from satellite telemetry or passive acoustics) beyond the confines of the ASAMM study area in the WBS was not widely available prior to 2006, when a new tagging study commenced (Citta et al. 2021), so it is possible that maternal females and calves migrated farther north than surveys covered or migrated prior to or after surveys occurred. The less dramatic differences in calf ratio since the early 2000s may also be related to the increase in BCB population size. This population was estimated at 6,928 (coefficient of variation $(C V)=0.120$ ) whales in 1988 (Zeh and Punt 2005; Givens and Heide-Jørgensen 2021) and $16,820(\mathrm{CV}=0.052$; based on passive acoustic and ice-based visual surveys) whales in 2011 (Givens et al. 2016), and is not considered to be at carrying capacity (Muto et al. 2021). As the bowhead whale population size increased, so, too, would the presence of reproductive age females and the number of calves in the population. Furthermore, bowhead whale body condition improved from 1989 to 2011, positively correlated with summer sea ice loss in the WBS (George et al. 2015), and preliminary data for 1990-2016 indicate continued improvements in body condition (Stimmelmayr et al. 2018). Improved body condition is favorable for pregnancy and parturition (Boyd et al. 1999).

Improved body condition is likely linked to increased primary productivity. Primary productivity in the Beaufort sector of the Arctic Ocean increased by 53\% from 1998 to 2012 (Arrigo and Van Dijken 2015) due to the decrease in summer sea ice and increase in ice-free days, a trend that has continued since 2012 (Frey et al. 2017). Increased primary productivity and subsequent secondary productivity may enhance bowhead whale feeding opportunities in summer and fall (Moore and Laidre 2006), although advection of prey from the northern Bering Sea is also likely important (Moore 2016). East of Point Barrow is a welldocumented bowhead whale foraging hot spot (Citta et al. 2015; Kuletz et al. 2015). Here, krill may become trapped during specific oceanographic conditions to provide foraging opportunities for bowhead whales during late summer and autumn (Ashjian et al. 2010). Ephemeral foraging opportunities, where localized aggregations of bowhead whale prey are dense enough to attract hundreds of whales, are less well understood, but were documented by ASAMM throughout the WBS study area on several occasions (Ferguson et al. 2021). For example, hundreds of bowhead whales were observed feeding throughout September 2014 in the shallow water just beyond the barrier islands of the central Alaska Beaufort Sea, likely taking advantage of dense prey aggregations resulting from the combined effects of freshwater runoff and upwelling favorable winds (Okkonen et al. 2018). In addition, an extremely large feeding aggregation (nearly 500 bowhead whales) was documented on one day in August 2016 north of Harrison Bay in the central Alaska Beaufort Sea (Clarke et al. 2018; Ferguson et al. 2021), an area that had not been previously identified as an important feeding area for bowhead whales. Stomach contents of bowhead whales harvested by three communities along the northern Alaska coastline each fall also indicate that feeding can be widespread and frequent (Sheffield and George 2021). Bowhead whales are also known to feed in winter in the northern Bering Sea, as documented from satellite telemetry, stomach content analyses, stable isotope analyses, and shore-based observations (Citta et al. 2015, 2021; Sheffield and George, 2021; Schell and Saupe, 1993) although the relative importance of winter feeding to the population is unknown.

Interannual variations in wind forcing over the Pacific Arctic region have been shown to drive corresponding variations in a variety of regional ecosystem components: water mass volumes and the timing of sea ice retreat (Okkonen et al. 2019), krill abundance and population age structure (Ashjian et al. 2021; Okkonen et al. 2020), and gray whale habitat 
usage (Moore et al. 2021, In review). Wind characteristics have been used as proxies to direct sampling for bowhead whale prey. Although bowhead whale calves are likely not yet feeding on krill and other invertebrate prey, maternal and pre-maternal females would be. The quality and quantity of feeding by reproductive age female BCB bowhead whales throughout their range in any given year are likely related to successful conception and calving success, but that link has not yet been established. Additional investigations into the relationships between oceanographic phenomena and bowhead whale calf occurrence are needed to corroborate this finding.

\section{Study limitations}

Aerial surveys, like any data collection method, have well-known limitations. Linetransect aerial surveys are "snapshots" of information specific to relatively small spatiotemporal fragments, and do not normally allow for in-depth behavioral investigation. The addition of circling to ascertain species identification, determine group size, and presence or absence of calves provided only a slightly longer exposure to the sighting. Photographs of cow-calf pairs or solitary calves were collected during circling effort when possible, but the amount of time spent circling was also constrained by survey platform endurance and weather. Circling occurred less regularly and was not accurately recorded in the ASAMM database until 2009. The lack of circling undoubtedly negatively biased calf counts prior to 2009 , as evidenced by the $>60 \%$ of calves that were detected during circling by ASAMM from 2012 to 2019. In other words, calves are underrepresented in the ASAMM dataset prior to 2009 .

Aerial survey data collection was limited to daylight hours on days when conditions were acceptable for conducting surveys. Acceptable conditions included numerous combinations of visibility, sea state, and cloud ceilings, some of which (e.g., good visibility, low sea state, and cloud ceilings $>305 \mathrm{~m}$ ) were more conducive to cetacean detection, particularly calf detection. The ASAMM study had multiple objectives each year (e.g., Clarke et al. 2020) that, at times, conflicted with each other. Although BCB bowhead whales were one of the targeted species, additional tasking occasionally demanded a shared focus. For example, in addition to conducting BCB bowhead whale abundance surveys in August 2019 (Clarke et al. 2020), ASAMM incorporated extra transects north of the study area in 2012 and 2016 to focus on Eastern Chukchi Sea beluga abundance (Lowry et al. 2017; Givens et al. 2019), and in 2015 ASAMM was involved in a study comparing the efficacy of crewed versus uncrewed aircraft for conducting line-transect surveys targeting large mysticetes (Ferguson et al. 2018). Time and effort supporting these unique objectives was time and effort that was not spent conducting $\mathrm{BCB}$ bowhead whale line-transect surveys.

Aerial surveys may also be constrained by survey platform endurance and pilot and observer fatigue. ASAMM had a very large study area, including not only the WBS (and the EBS in August 2019) but also the northeastern Chukchi Sea, for a total study area that exceeded $253,000 \mathrm{~km}^{2}$. Some parts of the ASAMM study area were more difficult to survey than others because of the long (e.g., hundreds of kilometres) transits from bases of operation, which were necessarily situated where fuel and lodging were available. Over the nearly four decade period that ASAMM surveys were conducted, multiple survey platforms were used that were not strictly comparable (see Clarke et al. 2016 for details on differences), and subtle but important changes occurred in survey methodologies including the introduction of CAPs protocols in 2018 (Clarke et al. 2019). Observer experience on ASAMM surveys varied from 1 to $>20$ years in any given year.

Some bowhead whale calf sightings may have been repeat sightings of individuals detected during ASAMM surveys earlier in the year. ASAMM collected aerial photos of approximately one-third of the bowhead whale cow-calf pairs sighted from 2012 to 2019, 
and preliminary analyses of images collected in 2017 found no intra-annual resightings (Marine Mammal Laboratory, Aerial Surveys of Arctic Marine Mammals, unpublished data, 2017) indicating that repeat sightings may be uncommon. Assuming there were a few repeat calf sightings within annual datasets, any bias linked to possible calf resightings would likely be similar in all years due to the consistency in the spatio-temporal allocation of survey effort, allowing for comparisons between years of calf ratios and sighting rates.

\section{Conclusions}

The BCB bowhead whale stock has rebounded from severe population depletion due to several decades of commercial whaling (Givens and Heide-Jørgensen 2021). Their success as a species depends on several factors, one of which is successful calf recruitment. Results from ASAMM surveys conducted from 2012 to 2019 provided valuable insight into calf ecology in the WBS that would have been difficult to obtain by other means. Data on BCB bowhead whale calves have historically been based on several sources, including systematic aerial surveys and aerial photo mark-recapture, ice-based censuses, and postmortem examinations (Tarpley et al. 2021). Ice-based censuses are not likely to continue due to the instability of spring sea ice, and broad-scale aerial surveys like the ASAMM project have been discontinued. The only means of estimating calf production may be limited to post-mortem examinations of whales taken during annual subsistence hunting, and those results may be skewed because subsistence whalers often target whales of a certain size and try to avoid taking very small whales (calves) or maternal females. Continued monitoring of this population and its habitat using several complementary methods (each with inherent biases), including aerial surveying with brief circling, shore observations, passive acoustic monitoring, and satellite telemetry, is essential to enact appropriate conservation and management efforts to ensure its continued success.

\section{Acknowledgements}

Funding for, and co-management of, aerial surveys in the WBS were provided by the Bureau of Ocean Energy Management (BOEM), Alaska OCS Region, under Interagency Agreement Nos. M07RG13260, M11PG00033, M16PG00013, and M17PG00031, where we particularly appreciated the support and guidance of Cathy Coon, Jeffrey Denton, Carol Fairfield, Charles Monnett, Rick Raymond, and Dee Williams. The ASAMM project was co-managed by the Marine Mammal Laboratory, Alaska Fisheries Science Center, NOAA, where we appreciated the support and assistance of Robyn Angliss, Stefan Ball, John Bengtson, Phil Clapham, Mary Foote, Nancy Friday, Kim Shelden, and Janice Waite. Mike Hay, of XeraGIS, provided invaluable and timely software support. Numerous observers, pilots, mechanics, flight followers, and other staff contributed mightily to the success of ASAMM by conducting surveys safely and effectively, collecting high quality data, and carrying out numerous analyses. We would especially like to acknowledge Clearwater Air, Inc., and Andrew Harcombe for their consummate aerial survey support. Craig George and Raphaela Stimmelmayr (North Slope Borough Department of Wildlife Management), and Phil Clapham (MML-NOAA) provided constructive feedback during the development of this manuscript. Kim Shelden (MML-NOAA) and Sue Moore (Center for Ecosystem Sentinels, University of Washington) provided a technical review of the current manuscript. We also appreciate the helpful comments from two anonymous reviewers.

\section{References}

Arrigo, K.R., and van Dijken, G.L. 2015. Continued increases in Arctic Ocean primary production. Progr Oceanogr, 136: 60-70. doi: 10.1016/j.pocean.2015.05.002. 
Ashjian, C.J., Braund, S.R., Campbell, R.G., George, J.C., Kruse, J., Maslowski, W., et al. 2010. Climate variability, oceanography, bowhead whale distribution, and Inupiat subsistence whaling near Barrow, Alaska. Arctic, 63(2): 179-194. doi: 10.14430/arctic973.10.14430/arctic973.

Ashjian, C.J., Campbell, R.G., and Okkonen, S.R. 2021. Biological environment. In The bowhead whale. Edited by J.C. George, and J.G.M. Thewissen. Academic Press, Cambridge. pp. 403-416.

Bivand, R., and Lewin-Koh, N. 2019. maptools: tools for reading and handling spatial objects. R package version 0.9-9. Available from https://CRAN.R-project.org/package=maptools.

Bivand, R., and Rundel, C. 2019. rgeos: interface to geometry engine - open source ('GEOS'). R package version 0.5-2. Available from https//CRAN.R-project.org/package=rgeos.

Bivand, R., Keitt, T., and Rowlingson, B. 2019. rgdal: bindings for the 'Geospatial' data abstraction library. R package version 1.4-8. Available from https://CRAN.R-project.org/package=rgdal.

Bivand, R.S., Pebesma, E.J., and Gomez-Rubio, V. 2013. Applied Spatial Data Analysis with R. Springer, New York. 1-16 pp.

Blackwell, S.B., Richardson, W.J., Greene, C.R., and Streever, B. 2007. Bowhead whale (Balaena mysticetus) migration and calling behaviour in the Alaskan Beaufort Sea, autumn 2001-04; an acoustic localization study. Arctic, 60(3): 255-270.

Bockstoce, J.R. 1986. Whales, ice, \& men. University of Washington Press, Seattle, Washington, USA.

Boyd, I.L., Lockyer, C., and Marsh, H.D. 1999. Reproduction in marine mammals. In Biology of marine mammals. Edited by J.E. Reynolds II, and S.A. Rommel. Smithsonian Institution Press, Central Washington, D.C. pp. 218-286.

Buckland, S.T. 2001. Introduction to distance sampling: estimating abundance of biological populations. Oxford University Press, Oxford, UK.

Citta, J.J., Quakenbush, L.T., Okkonen, S.R., Druckenmiller, M.L., Maslowski, W., Clement-Kinney, J., et al. 2015. Ecological characteristics of core-use areas used by Bering-Chukchi-Beaufort (BCB) bowhead whales, 2006-2012. Progr Oceanogr, 136: 201-222. doi: 10.1016/j.pocean.2014.08.012.

Citta, J.J., Quakenbush, L., and George, J.C., 2021. Distribution and behavior of Bering-Chukchi-Beaufort bowhead whales as inferred by telemetry. In The bowhead whale. Edited by J.C. George, and J.G.M. Thewissen. Academic Press, Cambridge. pp. 31-56.

Clarke, J.T., Kennedy, A.S., and Ferguson, M.C. 2016. Bowhead and gray whale distributions, sighting rates, and habitat associations in the eastern Chukchi Sea, summer and fall 2009-2015, with a retrospective comparison to 1982-91. Arctic, 69(4): 359-377. doi: 10.14430/arctic4597.

Clarke, J.T., Ferguson, M.C., Willoughby, A.L., and Brower, A.A. 2018. Bowhead and beluga whale distributions, sighting rates, and habitat associations in the western Beaufort Sea, summer and fall 2009-16, with a retrospective comparison to 1982-91. Arctic, 71(2): 115-138. doi: 10.14430/arctic4597.

Clarke, J.T., Brower, A.A., Ferguson, M.C., and Willoughby, A.L. 2019. Distribution and relative abundance of marine mammals in the eastern Chukchi and western Beaufort seas, 2018. Annual Report, OCS Study BOEM 2019-021. Marine Mammal Laboratory, Alaska Fisheries Science Center, Seattle, WA. 98115-6349. Available from http:// www.afsc.noaa.gov/NMML/cetacean/bwasp/.

Clarke, J.T., Brower, A.A., Ferguson, M.C., Willoughby, A.L., and Rotrock, A.D. 2020. Distribution and relative abundance of marine mammals in the eastern Chukchi Sea, and eastern and western Beaufort Sea, and Amundsen Gulf, 2019. Annual Report, OCS Study BOEM 2020-027. Marine Mammal Laboratory, Alaska Fisheries Science Center, Seattle, WA 98115-6349. Available from http://www.afsc.noaa.gov/NMML/cetacean/bwasp/.

Druckenmiller, M.L., Citta, J.J., Ferguson, M.C., Clarke, J.T., George, J.C., and Quakenbush, L., 2018. Trends in sea-ice cover within bowhead whale habitats in the Pacific Arctic. Deep-Sea Research Part II, 152: 95-107. doi: 10.1016/ j.dsr2.2017.10.017.

Craig, A.S., Herman, L.M., Gabriele, C.M., and Pack, A.A., 2003. Migratory timing of humpback whales (Megaptera novaeangliae) in the central North Pacific varies with age, sex and reproductive status. Behaviour, 140: 981-1001. doi: $10.1163 / 156853903322589605$.

Craig, A.S., Herman, L.M., Pack, A.A., and Waterman, J.O. 2014. Habitat segregation by female humpback whales in Hawaiian water: avoidance of males? Behaviour, 151: 613-631. doi: 10.1163/1568539X-00003151.

ESRI 2017. ArcGIS desktop: release 10.6.1. Environmental Systems Research Institute, Redlands, CA.

Ferguson, M.C., Angliss, R.P., Kennedy, A., Lynch, B., Willoughby, A., Helker, V., Brower, A.A., and Clarke, J.T. 2018. Performance of manned and unmanned aerial surveys to collect visual data and imagery for estimating arctic cetacean density and associated uncertainty. Journal of Unmanned Vehicle Syst, 6: 128-154. doi: 10.1139/juvs2018-0002.

Ferguson, M.C., Clarke, J.T., Brower, A.A., Willoughby, A.L., and Okkonen, S.R. 2021. Ecological variation in the western Beaufort Sea. In The bowhead whale. Edited by J.C. George, and J.G.M. Thewissen. Academic Press, Cambridge. pp. 365-379.

Frey, K.E., Comiso, J.C., Cooper, L.W., Eisner, L.B., Gradinger, R.R., Grebmeier, J.M., and Trembley, J.E., 2017. Arctic Ocean Primary Productivity. Arctic Report Card: Update for 2017.Available from http://www.arctic.noaa.gov/ Report-Card/Report-Card-2017/ArtMID/7798/ArticleID/701/Arctic-Ocean-Primary-Productivity.

George, J.C., Follman, E., Zeh, J., Sousa, M., Tarpley, R., Suydam, R., and Horstmann-Dehn, L., 2011. A new way to estimate the age of bowhead whales (Balaena mysticetus) using ovarian corpora counts. Can J Zoo, 89: 840-852. doi: 10.1139/z11-057.

George, J.C., Druckenmiller, M.L., Laidre, K.L., Suydam, R., and Person, B. 2015. Bowhead whale body condition and links to summer sea ice and upwelling in the Beaufort Sea. Progr Oceanogr, 136: 250-262. doi: 10.1016/ j.pocean.2015.05.001. 
George, J.C., Thewissan, J.G.M., Von Duyke, A., Breed, G.A., Suydam, R., Sformo, T.F., et al. 2021. Life history, growth, and form. In The bowhead whale. Edited by J.C. George, and J.G.M. Thewissen. Academic Press, Cambridge. pp. 87-115.

Givens, G.H., and Heide-Jørgensen, M.P. 2021. Abundance. In The bowhead whale. Edited by J.C. George, and J.G.M. Thewissen. Academic Press, Cambridge. pp. 77-86.

Givens, G.H., Ferguson, M.C., Clarke, J.T., Willoughby, A., Brower, A., and Suydam, R., 2019. Abundance of the eastern Chukchi Sea stock of beluga whales, 2012-17. Arctic, 73: 485-498. doi: 10.14430/arctic71592.

Givens, G.H., Edmondson, S.L., George, J.C., Suydam, R., Charif, R.A., Rahaman, A., et al. 2016. Horvitz-Thompson whale abundance estimation adjusting for uncertain recapture, temporal availability variation, and intermittent effort. Envirometrics, 27(3): 134-146. doi: 10.1002/env.2379.

Harwood, L.A., Auld, J., Joynt, A., and Moore, S.E. 2010. Distribution of bowhead whales in the SE Beaufort Sea during late summer, 2007-2009. Department of Fisheries and Oceans Canadian Science Advisory Secretariat Research Document 2009/111. iv + 22 p.

Harwood, L.A., Quakenbush, L.T., Small, R.J., George, J.C., Pokiak, J., Pokiak, C., et al. 2017. Movements and inferred foraging by bowhead whales in the Canadian Beaufort Sea during August and September, 2006-12. Arctic, 70(2): 161-176. doi: $10.14430 / \operatorname{arctic} 4648$.

Heide-Jørgensen, M.P., Laidre, K.L., Wiig, Ø., Postma, L., Dueck, L., and Bachman, L. 2010. Large-scale sexual segregation of bowhead whales. Endangered Species Res, 13: 73-78. doi: 10.3354/esr00315.

Hill, V., Ardyna, M., Lee, S.H., and Varela, D.E. 2018. Decadal trends in phytoplankton production in the Pacific Arctic Region from 1950-2012. Deep-Sea Research II, 152: 82-94. doi: 10.1016/j.dsr2.2016.12.015.

Hijmans, R.J., 2020. raster: Geographic Data Analysis and Modeling. R package version 3.0.2. Available from http:// CRAN.R-project.org/package=raster.

Jakobsson, M., Mayer, L.A., Coakley, B., Dowdeswell, J.A., Forbes, S., Fridman, B., et al. 2012. The International Bathymetric Chart of the Arctic Ocean (IBCAO) Version 3.0, Geophys Res Lett, 39: L12609. doi: 10.1029/ 2012 g1052219.

Koski, W.R., and Miller, G.W. 2009. Habitat use by different size classes of bowhead whales in the central Beaufort Sea during late summer and autumn. Arctic, 62(2): 137-150. doi: 10.14430/arctic127.

Koski, W.R., Davis, R.A., Miller, G.W., and Withrow, D.E. 1993. Reproduction. In The bowhead whale. Edited by J.J. Burns, J.J. Montague, and C.J. Cowles. The Society for Marine Mammalogy, Lawrence, Kansas. pp. 239-274.

Koski, W.R., Miller, G.W., and Davis, R.A. 1988. The potential effects of tanker traffic on the bowhead whale in the Beaufort Sea. Environmental Studies. LGL Limited, King City, Ontario. 50 pp.

Kuletz, K.J., Ferguson, M.C., Hurley, B., Gall, A.E., Labunski, E.A., and Morgan, T.C., 2015. Seasonal spatial patterns in seabird and marine mammal distribution in the eastern Chukchi and western Beaufort seas: identifying biologically important pelagic areas. Progr Oceanogr, 136: 175-200. doi: 10.1016/j.pocean.2015.05.012.

Lowry, L.F., and Frost, K.J. 1984. Foods and feeding of bowhead whales in western and northern Alaska. Sci Rep Whales Res Inst, 35: 1-16. Available from http://www.adfg.alaska.gov/static/home/library/pdfs/wildlife/ research_pdfs/84_lowry_frost_food_feeding_bowhead_western_northern_ak.pdf.

Lowry, L.F., Kingsley, M.C.S., Hauser, D.D.W., Clarke, J., and Suydam, R., 2017. Aerial survey estimates of abundance of the eastern Chukchi Sea stock of belugas whales (Delphinapterus leucas) in 2012. Arctic, 70(3): 273-286. doi: $10.14430 / \operatorname{arctic} 4667$.

Melnikov, V.V., and Zeh, J.E. 2007. Chukotka Peninsula counts and estimates of the number of migrating bowhead whales (Balaena mysticetus). J Cetacean Res Manag 91(1): 29-35.

Moore, S.E., 1992. Summer records of bowhead whales in the northeastern Chukchi Sea. Arctic, 45(4): $398-400$.

Moore, S.E., 2016. Is it 'boom times' for baleen whales in the Pacific Arctic region? Biol Lett, 12: 20160251. doi: 10.1098/rsbl.2016.0251. PMID: 27601724.

Moore, S.E., 2018. Climate change. In Encyclopedia of marine mammals. Edited by B.E. Würsig, J.G.M. Thewissen, K.M. Kovacs. Elsevier/Academic Press, Burlington, MA. pp. 194-197.

Moore, S.E., and Laidre, K.L., 2006. Trends in sea ice cover within habitats used by bowhead whales in the western Arctic. Ecol Appl 16(3): 932-944. doi: 10.1890/1051-0761(2006)016[0932:TISICW]2.0.CO;2. PMID: 16826993.

Moore, S.E., and Reeves, R.R., 1993. Distribution and Movement. In The bowhead whale. Edited by J.J. Burns,

J.J. Montague, and C.J. Cowles. The Society for Marine Mammalogy, Lawrence, Kansas. pp. 313-386.

Moore, S.E., George, J.C., Coyle, K.O., and Weingartner, T.J., 1995. Bowhead whales along the Chukotka coast in Autumn. Arctic 48(2): 155-160. doi: 10.14430/arctic1237.

Moore, S.E., Stafford, K.M., and Munger, L.M. 2010. Acoustic and visual surveys for bowhead whales in the western Beaufort and far northeastern Chukchi seas. Deep-Sea Res II, 57: 153-157. doi: 10.1016/j.dsr2.2009.08.013.

Moore, S.E., Stafford, K.M., Melling, H., Berchok, C., Wiig, O., Kovacs, K.M., et al. 2012. Comparing marine mammal acoustic habitats in Atlantic and Pacific sectors of the High Arctic: year-long records from Fram Strait and the Chukchi Plateau. Polar Biol, 35: 475-480. doi: 10.1007/s00300-011-1086-y.

Moore, S.E., Clarke, J.T., Okkonen, S.R., Grebmeier, J.M., Berchok, C.L., and Stafford, K.M.. In review. Changes in gray whale phenology and distribution related to prey variability and ocean biophysics in the northern Bering and eastern Chukchi seas. PLOS One.

Moore, S.E., George, J.C., and Reeves, R.R. 2021. Bowhead whale ecology in changing high-latitude ecosystems. In The bowhead whale. Edited by J.C. George, and J.G.M. Thewissen. Academic Press, Cambridge. pp. 417-427.

Muto, M.M., Helker, V.T., Delean, B.J., Young, N.C., Freed, J.C., Angliss, R.P., et al. 2021. Alaska marine mammal stock assessments, 2020. U.S. Department of Commerce NOAA Technical Memorandum NMFSAFSC-421, Washington, DC. 398 pp. 
Okkonen, S.P., Ashjian, D.J., Campbell, R.G., Clarke, J.T., Moore, S.E., and Taylor, K.D., 2011. Satellite observations of circulation features associated with a bowhead whale feeding 'hotspot' near Barrow, Alaska. Remote Sensing Environ, 115: 2168-2174. doi: 10.1016/j.rse.2011.04.024.

Okkonen, S.R., Clarke, J.T., and Potter, R.A., 2018. Relationships among high river discharges, upwelling events, and bowhead whale (Balaena mysticetus) occurrence in the central Alaskan Beaufort Sea. Deep-Sea Research Part II, 152: 195-202. doi: 10.1016/j.dsr2.2016.11.015.

Okkonen, S.R., Ashjian, C.J., Campbell, R.G., and Alatalo, P., 2019. The encoding of wind forcing into the Pacific Arctic pressure head, Chukchi Sea ice retreat and late-summer Barrow Canyon water masses. Deep-Sea Research Part II, 162: 22-31. doi: 10.1016/j.dsr2.2018.05.009.

Okkonen, S.R., Ashjian, D.J., Campbell, R.G., and Alatalo, P., 2020. Krill diel vertical migration: a diagnostic for variability of wind forcing over the Beaufort and Chukchi Seas. Progr Oceanogr, 181(102265): 102265. doi: 10.1016/j.pocean.2020.102265.

Pebesma, E.J., and Bivand, R.S., 2005. Classes and methods for spatial data in R. R News, 5(2): 9-13. Available from http://cran.r-project.org/doc/Rnews/.

R Core Team 2019. R: A language and environment for statistical computing. R Foundation for Statistical Computing, Vienna, Austria. Available from http://www.R-project.org/.

Rice, D.W., Wolman, A.A., and Braham, H.W., 1984. The gray whale, Eschrichtius robustus. Marine Fish Rev, 46(4):

7-14. Available from https://spo.nmfs.noaa.gov/sites/default/files/pdf-content/MFR/mfr464/mfr4643.pdf.

Richter-Menge, J., Druckenmiller, M.L., and Jeffries, M. 2019. Arctic Report Card 2019. Available from https:// www.arctic.noaa.gov/Report-Card.

Schell, D.M., and Saupe, S.M. 1993. Feeding and growth as indicated by stable isotopes. In The bowhead whale. Edited by J.J. Burns, J.J. Montague, and C.J. Cowles. The Society for Marine Mammalogy, Lawrence, Kansas. pp. 491-509.

Sheffield, G., and George, J.C. 2021. Diet and prey. In The bowhead whale. Edited by J.C. George, and J.G.M. Thewissen. Academic Press, Cambridge. pp. 429-455.

Stimmelmayr, R., George, J.C., Willoughby, A., Clarke, J., Ferguson, M., Sheffield, G., et al. 2018. 2017 health report for the Bering-Chukchi-Beaufort seas bowhead whales - preliminary findings. Paper SC/67b/AWMP8 presented to the Scientific Committee of the International Whaling Commission, April 2018 (unpublished), Bled, Slovenia. Available from https:/|iwc.int/index

Tarpley, R.J., Hillmann, D.J., George, J.C., Thewissen, J.G.M. 2021. Female and male reproduction. In The bowhead whale. Edited by J.C. George, and J.G.M. Thewissen. Academic Press, Cambridge. pp. 185-211.

Wassman, P., 2015. Overarching perspectives of contemporary and future ecosystems in the Arctic Ocean. Progr Oceanogr, 139: 1-12. doi: 10.1016/j.pocean.2015.08.004.

Wood, S.N. 2017. Generalized additive models: an introduction with R. Chapman and Hall/CRC, Boca Raton, FL.

Würsig, B., and Clark, C., 1993. Behavior. In The bowhead whale. Edited by J.J. Burns, J.J. Montague, C.J. Cowles. The Society for Marine Mammalogy, Lawrence, Kansas. pp. 157-199.

Würsig, B., Dorsey, E.M., Fraker, M.A., Payne, R.S., and Richardson, W.J. 1985. Behavior of bowhead whales, Balaena mysticetus, summering in the Beaufort Sea: a description. Fish Bull US, 83(3): 357-377.

Zeh, J.E., and Punt, A.E. 2005. Updated 1978-2001 abundance estimates and their correlations for the BeringChukchi-Beaufort Seas stock of bowhead whales. J Cetacean Res Manag, 7: 169-175.

Zhang, X., Jung, T., Wang, M., Luo, Y., Semmler, T., and Orr, A. 2018. Preface to the Special Issue: Towards improving understanding and prediction of Arctic change and its linkage with Eurasian mid-latitude weather and climate. Adv Atmospheric Sci, 35(1): 1-4. doi: 10.1007/s00376-017-7004-7. 